\title{
Tomasz KLEPNER
}

tomasz.klepner@gmail.com

\section{GAZ Z ŁUPKÓW - SZANSA CZY ZAGROŻENIE?}

\section{ABSTRACT Shale gas - a chance or a threat?}

The article discusses advantages and threats from the prospective of shale gas extraction in Poland. It lists conditions necessary for the creation of shale gas Eldorado. The author attempts to explain the main effects of shale gas extraction, refutes false assumptions and discusses controversy surrounding gas extraction. The article analyses how the process may influence Poland's national security and geopolitical situation in Central Europe. The author concludes with a statement that the shale gas extraction might open up great opportunities for Poland and the European Union if the initial assessments of shale gas resources in Poland have been confirmed.

KEYWORDS Poland, gas, shale, investment, security

\section{WSTĘP}

Odkąd w Polsce toczy się dyskusja nad wydobyciem gazu z łupków, pojawia się wiele informacji dotyczących opłacalności jego wydobycia i potencjalnego wpływu na środowisko. Prezentowane są niezliczone fakty, powstają mity, zwolennicy i przeciwnicy gazu z łupków zarzucają sobie nawzajem wprowadzanie opinii publicznej w błąd. Grupy interesów sterują dyskusją w korzystny dla siebie sposób, kształtując przy tym świadomość końcowego odbiorcy przekazu, czyli społeczeństwa. Celem tego artykułu jest próba rzetelnego przedstawienia zarówno warunków niezbędnych do zaistnienia tupkowego eldorado w Polsce, jak i wpływów ewentualnego wydobycia gazu z łupków na różne aspekty rzeczywistości. Na początek konieczne jest jednak wyjaśnienie, czym różni się gaz z łupków, zaliczany do gazu z rodziny niekonwencjonalnych, od gazu konwencjonalnego, a także zaprezentowanie krótkiej historii wydobycia gazu tego typu na świecie. 
Światowe zasoby ziemnego gazu niekonwencjonalnego mogą znacznie przewyższać zasoby gazu konwencjonalnego i stać się pokaźną rezerwą energetyczną. Można je podzielić następująco ${ }^{1}$ :

- gaz zamknięty (ang. tight gas) - znajdujący się w złożach o niskiej przepustowości $(\text { od }<0,1 \mathrm{mD} \text { do }<0,001 \mathrm{mD})^{2}$, umiejscowiony w porach o ograniczonych połączeniach między sobą;

- metan pokładów węgla kamiennego (ang. coal bed methane - CBM);

- hydraty gazu ziemnego - brak opracowanej efektywnej technologii pozwalającej na pozyskiwanie tego gazu;

- gaz z łupków (ang. shale gas) - gaz w łupkach, czyli skałach ilasto-mułowcowych, który charakteryzuje sięm.in. naturalnym systemem szczelin, dużą miąższościąi rozciągłością oraz bardzo niską przepustowością matrycy skalnej; w złożach gazu typu shale gas brak jest wyraźnych warstw izolujących czy pułapek strukturalnych.

Wydobywanie gazu z lupków na skale przemysłową odbywa się jedynie w Stanach Zjednoczonych i w Kanadzie. W tych państwach rozwinęła się technologia pozwalająca na opłacalne wydobywanie tego typu gazu niekonwencjonalnego. Koszty wydobycia w Stanach Zjednoczonych są obecnie zdecydowanie niższe niż koszty importu gazu ziemnego przy pomocy gazociągów lub gazoportów w formie skroplonej (LNG). Początki wydobycia datuje się na rok 1981, kiedy to rozpoczęto masowe wykonywanie odwiertów. Obecnie Stany Zjednoczone uzyskują ok. 12\% konsumowanego w kraju gazu z warstw lupkowych ${ }^{3}$.

W związku z tym, że gaz z łupków wydobywa się głównie w Ameryce Północnej, technologie niezbędne do przeprowadzania tego procesu posiadają przede wszystkim wielkie zachodnie koncerny, takie jak ConocoPhillips, Exxon, Chevron czy Tallisman. Dlatego należy przypuszczać, że potencjalne wydobycie w Polsce przeprowadzane będzie w strategicznej współpracy z koncernami posiadającymi technologie i doświadczenie.

Europa jest kontynentem stosunkowo ubogim w złoża gazu z łupków, przynajmniej w porównaniu z obiema Amerykami oraz Azją. Według raportu przygotowanego przez Amerykańską Agencję Informacji ds. Energii (EIA) oraz Advanced Research Institute (ARI) same chińskie zasoby tego surowca przewyższają europejskie ponad dwukrotnie (ok. 36 bln $\mathrm{m}^{3}$ w porównaniu z ok. 17,7 bln $\left.\mathrm{m}^{3}\right)^{4}$. Jednakże dla Europy, której wydobywalne zasoby gazu konwencjonalnego są na wyczerpaniu, liczba ta w dalszym ciągu może mieć strategiczne znaczenie. W przypadku Polski te dane mogą być jeszcze bardziej opty-

S. Rychlicki, J. Siemek, Gaz niekonwencjonalny - charakterystyka ztóż i technologia wydobycia, [w:] Gaz niekonwencjonalny - szansa dla Polski i Europy? Analiza i rekomendacje, red. I. Albrycht, Kraków 2011, s. 24.

$2 \mathrm{mD}$ (milidarcy) - jednostka przepuszczalności ośrodków porowatych. Dla porównania przepuszczalność złóż gazu konwencjonalnego o wysokich parametrach zasobowych i eksploatacyjnych kształtuje się w okolicach $100 \mathrm{mD}$.

3 S. Rychlicki, J. Siemek, Gaz niekonwencjonalny - charakterystyka..., s. 26.

4 World Shale Gas Resources: An Initial Assessment of 14 Regions Outside the United States, U.S. Energy Information Administration, 2011, [online] http://www.eia.gov/analysis/studies/worldshalegas/ pdf/fullreport.pdf, 3 IX 2012. 
mistyczne. Zakłada się, że baseny gazu niekonwencjonalnego występują w północnej i wschodniej części kraju, w pasie ciągnącym się od środkowo-południowego Pomorza, przez wschodnie Mazowsze, po wschodni region Lubelszczyzny (łupki dolnopaleozoiczne) oraz w południowo-zachodniej części kraju (hybryda łupków dolnokarbońskich i piaskowców z gazem zamkniętym). W 2009 r. powstał pierwszy raport, w którym oszacowano potencjalne polskie wydobywalne zasoby gazu z łupków. Jego autorem była grupa badawcza Wood Mackenzie, która oszacowała wydobywalne zasoby gazu typu shale gas na ok. 1,4 bln $\mathrm{m}^{3}$, analizując jedynie złoża z basenu dolnopaleozoicznego ${ }^{5}$.

Niewiele później powstał kolejny raport sporządzony przez ARI, który szacował zasoby tych samych złóż na poziomie ponad dwukrotnie większym - ok. 3 bln $\mathrm{m}^{36}$. Ten sam Instytut prowadził w 2011 r. badania na zlecenie EIA; dane zawarte w tym raporcie były jeszcze bardziej perspektywiczne - wydobywalne zasoby gazu z łupków w tym basenie oszacowano na 5,3 bln $\mathrm{m}^{3}$. Według opinii Pawła Poprawy, zajmującego się badaniami w zakresie rozpoznawania potencjału występowania niekonwencjonalnych złóż węglowodorów w Polsce, można wnioskować, że wraz z upływem czasu i pogłębianiem wiedzy na temat geologicznej struktury basenów oraz gazu z lupków dane dotyczące zasobów tego typu gazu będą się zwiększać ${ }^{7}$. Swój wniosek opiera on między innymi na analogicznej sytuacji, która miała miejsce w Stanach Zjednoczonych podczas szacowania potencjalnych zasobów gazu niekonwencjonalnego. Jak się jednak okazuje, opinia ta nie musi być prorocza. Jak wynika z najnowszych badań przeprowadzonych przez Państwowy Instytut Geologiczny z marca 2012 r., na obszarze basenu dolnopaleozoicznego zasoby gazu z lupków mogą wynosić maksymalnie $1,92 \mathrm{bln} \mathrm{m}^{3}$, a najbardziej prawdopodobne jest, że mieszczą się w przedziale 346-760 $\mathrm{mld} \mathrm{m}^{38}$. Są to dane niższe, niż prognozowane przez Wood Mackenzie jeszcze w 2009 r.

Kwestią wymagającą odrębnego omówienia jest technologia i sposób wydobywania gazu z łupków. Jedynymi skutecznymi technologiami są technologie wiercenia horyzontalnego i szczelinowania hydraulicznego. Wydobywanie gazu z łupków za pomocą tych sposobów jest najbardziej efektywne. Pewne kontrowersje wzbudza druga z wymienionych metod, dlatego zostanie ona przedstawiona nieco szerzej.

Szczelinowanie hydrauliczne polega na wprowadzeniu i wpompowaniu w grunt płynu szczelinującego, tzw. płuczki. Cały zabieg jest przeprowadzany w celu zwiększania przepustowości warstw skalnych zawierających złoża niekonwencjonalnego gazu. Co ciekawe, w Polsce metoda szczelinowania hydraulicznego przeprowadzana jest z sukcesem

Shale gas outlook: A U.S. perspective, KPMG Global Energy Institute, [online] http://www.kpmg.com/ Global/en/IssuesAndInsights/ArticlesPublications/shale-gas/Documents/shale-gas-us-outlook.pdf, 3 IX 2012.

6 Tamże.

7 P. Poprawa, Zasoby i potencjat gazu niekonwencjonalnego, [w:] Gaz niekonwencjonalny - szansa..., s. 119.

8 Ocena zasobów wydobywalnych gazu ziemnego i ropy naftowej w formacjach tupkowych dolnego paleozoiku w Polsce (basen battycko-podlasko-lubelski). Raport pierwszy, Państwowy Instytut Geologiczny - Państwowy Instytut Badawczy, 2012, s. 5, [online] http://www.pgi.gov.pl/pl/component/docman/ doc_download/771-raport-pl.html, 25 IX 2012. 
przy wydobywaniu gazu konwencjonalnego od lat 50. XX w. ${ }^{9}$ Kontrowersje wokół zabiegów szczelinowania hydraulicznego wynikają m.in. ze specyficznego składu chemicznego płuczki. Zarzuty dotyczące tej metody zostaną przedstawione w dalszej części artykułu.

Rysunek 1. Mapa koncesji na poszukiwanie i rozpoznawanie gazu lupkowego (stan na dzień 28.02.2013 r.)
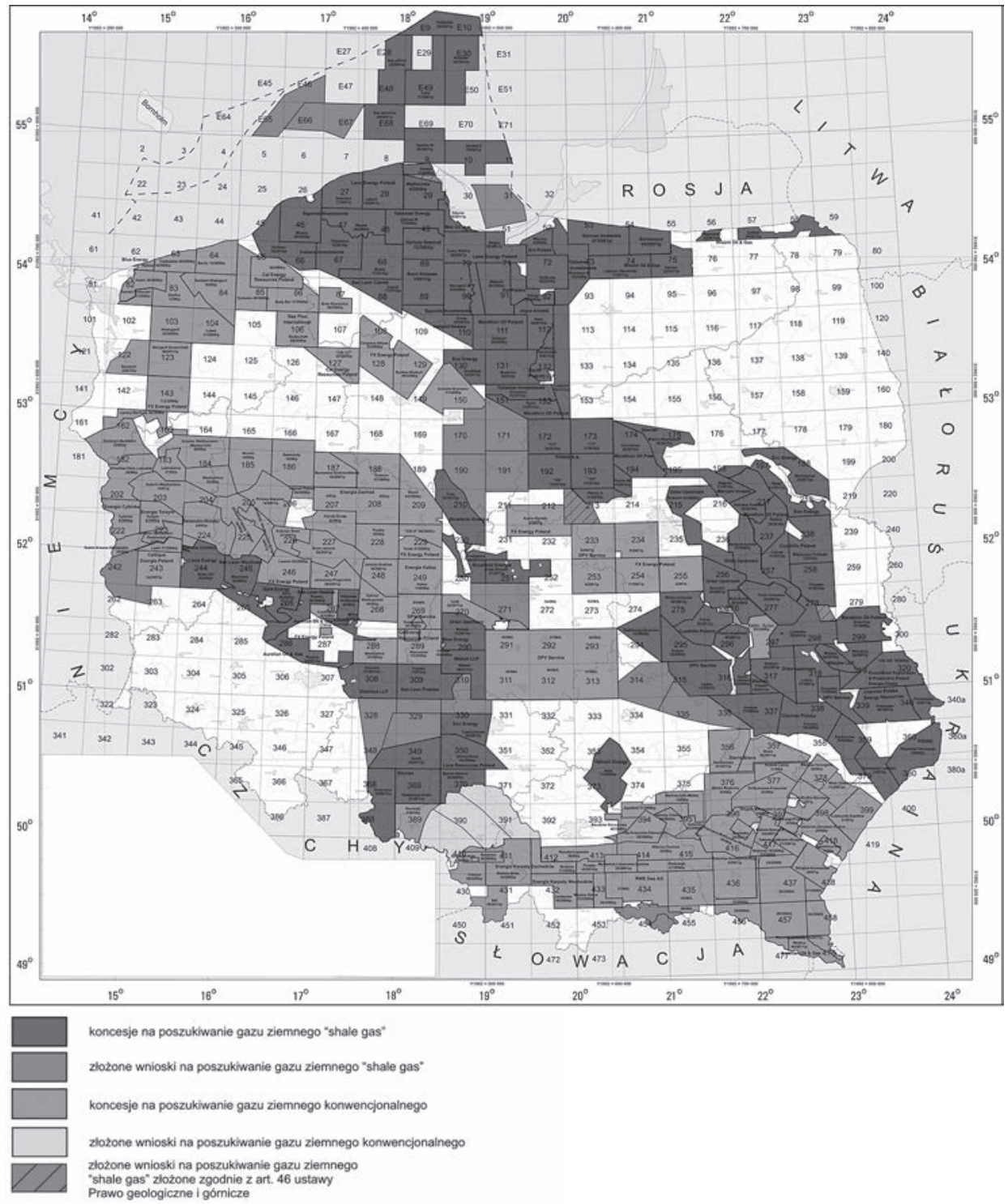

Źródło: www.mos.gov.pl/g2/big/2013_03/ae1f2501b896af9664738483e5725318.jpg, 31 VIII 2012.

9 Szczelinowanie hydrauliczne: Polacy od 60 lat stosuja kontrowersyjna technologie, [online] http://forsal.pl/artykuly/611640,szczelinowanie_hydrauliczne_polacy_od_60_lat_stosuja_kontrowersyjna_ technologie.html, 31 VIII 2012. 
Uzyskiwanie zgody na poszukiwanie złóż gazu z łupków odbywa się obecnie w Polsce w trybie przetargu. Wcześniej koncesje były przyznawane bezprzetargowo, a rząd już zastanawia się nad powrotem do poprzednich uregulowań prawnych. Sprawy związane z uzyskiwaniem koncesji reguluje Ustawa o Prawie geologicznym i górniczym z dnia 9 czerwca 2011 r. (zwana dalej Nowym Prawem Geologicznym), która weszła w życie 1 stycznia 2012 r. Zgodnie z postanowieniami Nowego Prawa Geologicznego ogłoszenie przetargu obejmuje z założenia wszystkie obszary koncesyjne w Polsce. Koncesję na poszukiwanie gazu z łupków wydaje po rozstrzygnięciu przetargu Minister Środowiska. Jest ona realizowana na podstawie umowy o ustanowieniu użytkowania górniczego zawieranej pomiędzy Ministrem a zwycięzcą przetargu. Koncesji udziela się na określony czas, nie dłuższy jednak niż 50 lat. Nowe Prawo Geologiczne nie pozwala na przedłużenie czasu trwania koncesji na wypadek niedokończenia prac określonych w umowie. Skutkuje to tym, że dalsze prace na danym obszarze koncesyjnym będą wymagać uzyskania nowej koncesji.

Według danych Ministerstwa Środowiska na dzień 1 sierpnia 2012 r. wydano łącznie 111 koncesji na poszukiwanie i rozpoznawanie złóż gazu z łupków w Polsce ${ }^{10}$. Obszar koncesyjny przedstawia Rysunek 1 . Kolorem ciemnoczerwonym zaznaczono obszary, na których przyznano koncesje na poszukiwanie złóż gazu niekonwencjonalnego typu shale gas, kolor jasnoczerwony to obszar, na którym złożono wnioski o na poszukiwanie złóż tego typu, natomiast pozostałe kolory dotyczą konwencjonalnych złóż gazu. Wśród firm, które obecnie posiadają omawiane koncesje, odnaleźć można m.in.: Chevron, ConocoPhillips, Total, Marathon, ENI, Tallisman, Nexen, PGNiG SA, Orlen, Lotos Petrobaltic, Petrolinvest, 3Legs, BNK Petroleum, RAG, Sorgenia, San Lion, Strzelecki Energy, Quadrilla, Composite Log, DPV Services.

\section{WARUNKI NIEZBĘDNE DO ZAISTNIENIA EUPKOWEGO ELDORADO}

Samo odnalezienie wydobywalnych złóż gazu z łupków nie będzie wystarczającym bodźcem do rozpoczęcia produkcji przemysłowej. Aby tupkowe eldorado mogło się ziścić, niezbędne jest spełnienie kilku kluczowych warunków.

Nie ulega wątpliwości, że zapewnienie dostaw dla odbiorców końcowych po atrakcyjnej cenie będzie możliwe tylko w przypadku zaistnienie jednolitego, wolnego rynku. Konieczna będzie liberalizacja prawna rynku gazowego. Przedsiębiorstwa staną przed wyzwaniem stosowania zasad wolnorynkowych i każde otrzyma równe szanse. W ten sposób możliwa będzie produkcja gazu niekonwencjonalnego na skalę przemysłową, co wraz z powyższym powinno zapewnić obniżenie cen gazu w Polsce.

W ramach doskonalenia własnej technologii warto nawiązać współpracę z podmiotami posiadającymi odpowiednią wiedzę na temat wydobycia gazu z łupków, głów-

10 Zestawienie koncesji na poszukiwanie $i$ rozpoznawanie ztóz gazu tupkowego w Polsce wraz $z$ ich lokalizacja wedtug stanu na dzień 1 sierpnia 2012 r., [online] http://www.mos.gov.pl/g2/big/2012_08/89223b29e1148090ca950f6c50913f7c.pdf, 31 VIII 2012. 
nie północnoamerykańskimi. Chodzi tu przede wszystkim o współpracę naukowo-badawczą i gospodarczą. Rozwijając wspólne doświadczenia w zakresie działalności poszukiwawczo-wydobywczej, można jednocześnie pogłębiać znajomość w innych gałęziach. Należy podjąć wspólne projekty badawcze czy przeprowadzać szkolenia ekspertów. Umowy o współpracy mógłby również zawierać postanowienia o transferze technologii, oczywiście przy poszanowaniu praw własności intelektualnej i informacji.

Aby gaz z łupków mógł być sprawnie dystrybuowany na terenie kraju oraz poza jego granice, potrzebna jest rewolucja w dziedzinie infrastruktury przesyłowej i magazynowej. Obecnie przesył gazu przez terytorium Polski odbywa się ze wschodu na zachód $i$ do tego jest przygotowana istniejąca infrastruktura. $Z$ tego punktu widzenia ważne są takie inwestycje, jak terminal LNG w Świnoujściu (aby eksportować tą drogą gaz niekonwencjonalny, konieczna będzie rozbudowa portu o skraplacze gazu), druga nitka Gazociągu Jamalskiego, gazociąg Północ-Południe, Baltic Pipe czy wreszcie mniejsze interkonektory lączące Polskę z sąsiadami. Więcej na ten temat zostanie powiedziane przy omawianiu kwestii ewentualnego eksportu gazu z łupków poza granice naszego kraju. Konieczna jest również rozbudowa infrastruktury magazynowej, ponieważ obecne możliwości rezerwowe gazu są niewystarczające w razie nagłego kryzysu i mogą negatywnie wpłynąć na bezpieczeństwo wewnętrzne Polski ${ }^{11}$.

Kolejnym warunkiem, który musi zostać spełniony, jest stworzenie odpowiedniego środowiska dla potencjalnych inwestorów. Warto rozważyć ustalenie poziomu rocznego limitu wydobycia gazu, tak aby jego rezerwy nie zostały wyczerpane zbyt szybko. Warto także wziąć pod uwagę utworzenie spółki, która z mocy prawa obejmowałaby część udziałów w koncesjach, stanowiąc w ten sposób pewnego rodzaju kontrolę i źródło dodatkowych wpływów dla skarbu państwa. Ostatnio pojawiła się koncepcja wyposażenia w odpowiednie atrybuty Narodowego Operatora Kopalń Energetycznych (NOKE). Miałby on nadzorować wszelką działalność związaną z poszukiwaniem i wydobyciem gazu i ropy ${ }^{12}$. Wśród potencjalnych propozycji przedstawia się także możliwości związania systemu opłat za koncesje i podatków z rynkiem gazu i realiami cenowymi panującymi na nim, a także utworzenie w ramach opłat eksploatacyjnych funduszu celowego, którego zadaniem byłoby wspieranie rozwoju technologii i finansowanie innowacyjnych badań ${ }^{13}$.

Niestety, istnieją również inne, nie zawsze w pełni zależne od woli decydentów bariery, które mogą uniemożliwić, spowolnić bądź znacząco utrudnić wydobycie gazu typu shale gas. Najważniejsze z nich to ${ }^{14}$ :

11 Opinia ekspertów oparta badaniami przedstawionymi w raporcie Instytutu Kościuszki: Bezpieczeństwo energetyczne Polski 2010 - raport otwarcia, red. P. Szlagowski, Kraków 2010.

12 T. Furman, Biznes obawia się nowych podatków, „Rzeczpospolita”, 16 X 2012, [online] http://www. rp.pl/artykul/938633,942781-Biznes-obawia-sie-nowych-podatkow.html, 16 X 2012.

13 A. Zawisza, Perspektywy rozwoju gazu niekonwencjonalnego w Polsce - system koncesyjno-podatkowy, [w:] Gaz niekonwencjonalny - szansa..., s. 179.

14 Opracowane na podstawie: J. Hardo, Strategia poszukiwań ztóż gazu ziemnego w tupkach, „Przegląd Geologiczny" 2010, vol. 58, nr 3, s. 250-258, [online] http://www.pgi.gov.pl/images/stories/artykuly/gaz_lupkowy/pg_2010_03_15.pdf, 29 VIII 2012; M. Kaliski, M. Krupa, A. Sikora, Perspektywy 
- rozmieszczenie części złóż gazu na obszarach Natura 2000, możliwość blokowania inwestycji przez organizacje ekologiczne;

- różnice geologiczne pomiędzy Europą a Ameryką, a co za tym idzie - brak pewności co do skuteczności ewentualnych implikacji doświadczeń północnoamerykańskich na gruncie europejskim;

- protekcjonizm krajowego rynku firm serwisowych (zwłaszcza wiertniczych);

- brak specjalistycznych urządzeń wiertniczych i wynikające z tego uciążliwe i długie procedury sprowadzania specjalistycznego sprzętu zza granicy;

- konieczność zakupu drogich technologii;

- brak specjalistów w kraju ${ }^{15}$;

- konieczność organizowania przetargów na wykonywanie wierceń, ich czas i cena;

- niejasność i częste zmiany przepisów, dotyczących zarówno prawa geologicznego, w tym prawa dostępu do informacji geologicznej (oraz jej wysoka cena), jak i ochrony środowiska, które niejednokrotnie nie uwzględniają specyfiki poszukiwań naftowych;

- brak zachęt w postaci ulg podatkowych, ostateczny kształt systemu opodatkowania wydobycia gazu z tupków;

- niedostateczna liberalizacja rynku gazu jako przyczyna niepewnej ceny gazu, w tym ceny politycznej ponoszonej przy imporcie gazu z Rosji;

- duża gęstość zaludnienia na niektórych obszarach bogatych w zasoby gazu z lupków;

- negatywne nastawienie lokalnych społeczności do wydobywania gazu z lupków.

Ostatni punkt jest o tyle ważny, że zarówno społeczności lokalne, jak i lokalne władze często są celowo wprowadzane w błąd, aby stanowić pierwszą linię oporu wobec potencjalnego wydobywania gazu z łupków. Wiąże się to z brakiem zaufania co do gazu z łupków, a także niedostateczną wiedzą obywateli na temat procesu i skutków jego wydobycia. Aby osiągnąć pełną przejrzystość w tym temacie, należy włączyć wszystkie zainteresowane grupy, w tym przedstawicieli grup prośrodowiskowych i innych społeczności, do dyskusji eksperckiej na temat wydobycia gazu z łupków. Pozwoli to na rozwianie wątpliwości i wykluczenie z obiegu nieprawdziwych informacji wprowadzających w bląd opinię publiczną.

Problemem natomiast nie jest, pomimo podnoszonych głosów ${ }^{16}$, umowa na import błękitnego paliwa z Rosji. Obecna - obowiązująca do 2022 r. - w pozytywnym świe-

wykorzystania gazu niekonwencjonalnego w Polsce. Potencjat wzrostu konsumpcji gazu ziemnego w sektorach pozaenergetycznych oraz gtówne bariery dla rozwoju sektora gazu niekonwencjonalnego, [w:] Gaz niekonwencjonalny - szansa..., s. 143-157; P. Kosowski, Obszary ryzyka mogace warunkować znaczenie sektora gazu tupkowego $w$ Polsce i jego wptyw na wartości realne w gospodarce, [w:] Wptyw wydobycia gazu tupkowego na rozwój spoteczno-ekonomiczny regionów - amerykańskie „success story” i potencjalne szanse dla Polski, red. I. Albrycht, Kraków 2012, s. 91-93.

15 Sposobem na przezwyciężenie tej oraz poprzedniej bariery może być chociażby zawieranie umów o współpracy pomiędzy polskimi a zagranicznymi podmiotami, o których była mowa wcześniej.

16 T. Kijewski, Perspektywy rozwoju wydobycia niekonwencjonalnych ztóż gazu ziemnego w kontekście zwiększenia bezpieczeństwa energetycznego RP, „Bezpieczeństwo Narodowe” 2010, nr 13, s. 107, [online] http://www.bbn.gov.pl/download.php?s=1\&id=4596, 29 VIII 2012. 
tle stawia ewentualne korzyści, jakie mogą płynąć z wydobywania gazu z łupków przez Polskę. Szacuje się bowiem, że rozpoczęcie wydobycia możliwe jest w ciągu najbliższych 10 lat, czyli w okresie wygaśnięcia bieżącego porozumienia. Może to być korzystny argument w ewentualnych negocjacjach z Rosją.

\section{WPŁYW WYDOBYCIA GAZU Z ŁUPKÓW - SZANSE I ZAGROŻENIA}

Wydobywanie gazu z łupków na skalę przemysłową może spowodować szereg implikacji. Należy więc rzetelnie zaprezentować ewentualne skutki tego procesu.

Przede wszystkim gaz z łupków, gdyby potwierdziły się optymistyczne informacje o jego wydobywalnych zasobach, mógłby być szansą na energetyczne uniezależnienie się Polski od wielkiego sąsiada ze wschodu - Rosji. Samowystarczalność gazowa kraju wpłynęłaby nie tylko na nasze bezpieczeństwo wewnętrzne, ale także na sytuację geopolityczną w regionie Europy Środkowej. Obecnie dominacja Gazpromu na europejskim rynku gazowym jest bezdyskusyjna. Ewentualny eksport gazu ziemnego z Polski pozwoliłby europejskim odbiorcom na dywersyfikację źródeł dostaw gazu. Koszt zakupu gazu z Polski byłby pozbawiony tzw. kosztów politycznych, przez co sam Gazprom musiałby się niejako dostosować do warunków cenowych narzucanych przez wolnorynkowe zasady. Co zrozumiałe, Polska odniosłaby korzyści z eksportu własnego gazu, stając się kluczowym graczem w ramach Unii Europejskiej. Aby osiągnąć sukces ekonomiczny związany ze sprzedażą wydobywanego u nas gazu z lupków, niezbędne są m.in. inwestycje w infrastrukturze przesyłowej. Sprzedaż gazu może odbywać się w kilku kierunkach. Przez odpowiednie przystosowanie budowanego terminalu LNG w Świnoujściu można by eksportować gaz w formie skroplonej drogą morską. Jednocześnie możliwe jest połączenie go za pomocą Gazociągu Północ-Południe z powstającym na chorwackiej wyspie Krk terminalem LNG Adria. Dodatkowe połączenie tego gazociągu z Gazociągiem Nabucco na terenie Węgier pozwoliłoby na zasilanie tej linii przesyłowej $\mathrm{z}$ trzech stron, realizując w ten sposób zapotrzebowanie dla krajów zachodniej Europy. Warta rozważenia jest w tym kontekście także budowa gazociągu Baltic Pipe łączącego Polskę z Danią. Strategiczne znaczenie może mieć budowa drugiej nitki Gazociągu Jamalskiego, która zwiększyłaby jego moc przesyłową z $30 \mathrm{mld} \mathrm{m}^{3}$ do ponad $65 \mathrm{mld} \mathrm{m}^{3}$ rocznie ${ }^{17}$.

Wykorzystanie tego gazociągu do przesyłu polskiego gazu jest jednak sprawą wartą osobnego omówienia, ze względu na skomplikowaną strukturę własnościową spółki EuRoPol Gaz S.A. będącej operatorem gazociągu na terenie Polski. Po 48\% udziałów mają w niej PGNiG SA oraz Gazprom. Pozostałe 4\% należy do Gas Trading S.A. Obecnie Gazprom posiada zakontraktowane 90\% przepustowości gazociągu, która wynosi $30 \mathrm{mld} \mathrm{m}^{3}$ rocznie, natomiast pozostałe 10\% należy do PGNiG. Należy przypusz-

17 M. Ruszel, Perspektywy eksportu gazu niekonwencjonalnego z Polski do krajów Europejskich, [w:] Gaz niekonwencjonalny-szansa..., s. 169-170. 
czać, że brak konsensusu będzie rozstrzygany na poziomie politycznym, co w naturalny sposób stawia polskie interesy w niekorzystnym świetle ${ }^{18}$.

Ostatnim, ale najważniejszym elementem w uktadance infrastrukturalnej są tzw. interkonektory, czyli połączenia z sąsiadami. Najważniejsze obecnie istniejące interkonektory to interkonektor Lasów na granicy z Niemcami o docelowej mocy przesyłowej $2 \mathrm{mld} \mathrm{m}^{3}$ oraz interkonektor w Cieszynie na granicy z Czechami o docelowej mocy 3 $\mathrm{mld} \mathrm{m}^{3}$. Dodatkowo istnieją plany budowy ważnego strategicznie interkonektora na granicy z Litwą, o mocy przesyłowej ok. $1 \mathrm{mld} \mathrm{m}^{3}$ gazu ziemnego, który połączyłby gazociągi Kowno-Alytus oraz Włocławek-Gdynia.

Kończąc analizę skutków wydobywania gazu z łupków na skale przemysłową, należy jeszcze przedstawić poziom aktualnej konsumpcji gazu ziemnego w Polsce wraz z prognozą związaną z łupkami. Obecna produkcja błękitnego paliwa w Polsce oscyluje na poziomie ok. $4 \mathrm{mld} \mathrm{m}^{3}$ rocznie, przy jednoczesnym poziomie konsumpcji równym $14 \mathrm{mld} \mathrm{m}^{3}$, co daje uzależnienie od importowanego gazu na poziomie $70 \%{ }^{19}$. Nawet w przypadku potencjalnego wzrostu konsumpcji, spowodowanego chociażby opisywanym wyżej wykorzystywaniem gazu z łupków w sektorze energoelektrycznym, Polska będzie mogła liczyć na kompletne uniezależnienie się od importowanego surowca i stanie się państwem gazowo samowystarczalnym.

Największa grupa zarzutów formułowanych przez przeciwników gazu z łupków dotyczy aspektów środowiskowych wydobycia błękitnego paliwa. Podnoszą oni alarm $\mathrm{m}$.in. z powodu gigantycznego zużycia wody, potrzebnej w procesie szczelinowania hydraulicznego. Dodatkowo przestrzegają przed negatywnymi skutkami ewentualnego przedostania się płynu szczelinującego do wód gruntowych, ponieważ zawiera on różnego typu związki chemiczne. Pierwszy zarzut wydaje się o tyle nietrafiony, że ilość wody potrzebnej przy szczelinowaniu hydraulicznym rzeczywiście jest duża, ale stosunkowo niewielka w porównaniu z całościowym zużyciem wody w regionie czy w kraju. I tak w przypadku klasycznego basenu Fort Worth i tupków Barnett (obszar pótpustynny) zużycie wody do szczelinowania ogótem stanowi zaledwie okoto $1 \%$ tacznej konsumpcji wody w tym obszarze ${ }^{20}$. Z innych badań Państwowego Instytutu Geologicznego wynika, że tylko Warszawa zużywa rocznie od 4 do 10 razy więcej wody, niż potrzebne będzie na wszystkie zabiegi szczelinowania hydraulicznego w całym kraju ${ }^{21}$. Większą ilość wody wykorzystuje się w przypadku mokrych płuczek wieżowych, używanych np. w elektrowniach. Także skład płuczki nie jest zagrożeniem dla środowiska naturalnego, ponieważ substancje chemiczne stanowią w nim maksymalnie 2\% składu (pozostałe to

18 Tamże, s. 169.

19 M. Kołaczkowski, Liberalizacja rynku gazu i wzrost bezpieczeństwa energetycznego [w:] Gaz niekonwencjonalny - szansa..., s. 127.

20 Środowiskowe aspekty poszukiwań i produkcji gazu ziemnego tupkowego i ropy naftowej tupkowej, Ministerstwo Środowiska oraz Państwowy Instytut Geologiczny - Państwowy Instytut Badawczy, 2011, s. 7, [online] http://www.mos.gov.pl/g2/big/2011_08/d048c148f02734c384a119266ba159b8.pdf, 29 VIII 2012.

21 G. Lewis, T. Smith, K.F. Perry, P. Poprawa, Wptyw poszukiwań $i$ wydobycia gazu niekonwencjonalnego na środowisko naturalne, [w:] Gaz niekonwencjonalny-szansa..., s. 47. 
woda i piasek) i występują w codziennym środowisku w powszechnym zastosowaniu (Tabela 1). Ważne jest zaznaczenie, że część płynu (zwykle ok. 25\%) wykorzystywana jest ponownie przy kolejnych zabiegach szczelinowania. Nie istnieje możliwość przedostania się płuczki do wód gruntowych i powierzchniowych, ponieważ cała procedura odbywa się poniżej strefy tych wód. Jak dotąd nie zaobserwowano takiej migracji, która stanowiłaby potencjalne zagrożenie. Ze względu na odpowiednie zabezpieczenia nie ma również zagrożenia kontaktu płuczki z zewnętrznymi warstwami wodonośnymi. Poza tym wodę pochodzącą z procesu szczelinowania hydraulicznego można bezpiecznie wprowadzać do zasobów wód pitnych po jej oczyszczeniu. Na razie takie zabiegi są zbyt kosztowne, lecz rozwój badań nad tym elementem pozwala sądzić, że w niedalekiej przyszłości tego typu przedsięwzięcia staną się bardziej opłacalne.

Tabela 1. Składniki płynu szczelinującego i ich powszechne zastosowanie

\begin{tabular}{|c|c|c|c|}
\hline Dodatek & $\begin{array}{l}\text { Składnik } \\
\text { chemiczny }\end{array}$ & Rola & Powszechne zastosowanie \\
\hline Kwas & $\begin{array}{l}\text { Kwas solny lub } \\
\text { chlorowodorowy }\end{array}$ & $\begin{array}{l}\text { Ułatwia rozpuszczanie } \\
\text { minerałów i powstanie pęk- } \\
\text { nięć w skale }\end{array}$ & Dodawany do wody basenowej \\
\hline $\begin{array}{l}\text { Środek } \\
\text { antybakteryjny }\end{array}$ & Aldehyd glutarowy & $\begin{array}{l}\text { Niszczy bakterie występu- } \\
\text { jące w wodzie, które wy- } \\
\text { twarzają produkty uboczne } \\
\text { powodujące korozje }\end{array}$ & $\begin{array}{l}\text { Środek odkażający, wykorzy- } \\
\text { stywany do sterylizacji narzędzi } \\
\text { lekarskich i dentystycznych }\end{array}$ \\
\hline Kruszarka & $\begin{array}{l}\text { Nadsiarczan } \\
\text { amonu }\end{array}$ & Opóźnia rozkład żelu & $\begin{array}{l}\text { Używany w środkach do ko- } \\
\text { loryzacji włosów, jako środek } \\
\text { dezynfekujący i w produkcji po- } \\
\text { wszechnie używanych plastiko- } \\
\text { wych artykułów gospodarstwa } \\
\text { domowego }\end{array}$ \\
\hline $\begin{array}{l}\text { Czynnik hamujący } \\
\text { korozję }\end{array}$ & Formamid & $\begin{array}{l}\text { Zapobiega korozji rur } \\
\text { okładzinowych }\end{array}$ & $\begin{array}{l}\text { Stosowany w przemyśle farma- } \\
\text { ceutycznym, produkcji włókien } \\
\text { akrylowych i plastiku }\end{array}$ \\
\hline $\begin{array}{l}\text { Czynnik umożli- } \\
\text { wiający sieciowanie }\end{array}$ & Sole boranowe & $\begin{array}{l}\text { Utrzymuje lepkość pły- } \\
\text { nu w miarę wzrastania } \\
\text { temperatury }\end{array}$ & $\begin{array}{l}\text { Obecny w środkach do prania, } \\
\text { mydłach do rąk i kosmetykach }\end{array}$ \\
\hline $\begin{array}{l}\text { Środek zmniejsza- } \\
\text { jący tarcie }\end{array}$ & $\begin{array}{l}\text { Destylator ropy } \\
\text { naftowej }\end{array}$ & $\begin{array}{l}\text { „Wygładza” wodę w celu } \\
\text { zminimalizowania tarcia }\end{array}$ & $\begin{array}{l}\text { Używany w przemyśle kosme- } \\
\text { tycznym, w tym produkcji } \\
\text { środków do pielęgnacji włosów, } \\
\text { paznokci i skóry oraz kosmety- } \\
\text { ków do makijażu }\end{array}$ \\
\hline Żel & $\begin{array}{l}\text { Guma guar lub } \\
\text { hydroksyceluloza }\end{array}$ & $\begin{array}{l}\text { Zwiększa gęstość wody (aby } \\
\text { mogła ona unieść piasek) }\end{array}$ & $\begin{array}{l}\text { Zagęszczacz; występuje w ko- } \\
\text { smetykach, produktach pie- } \\
\text { karniczych, lodach, pastach do } \\
\text { zębów, sosach i dressingach do } \\
\text { sałatek }\end{array}$ \\
\hline
\end{tabular}




\begin{tabular}{|c|c|c|c|}
\hline Dodatek & $\begin{array}{l}\text { Składnik } \\
\text { chemiczny }\end{array}$ & Rola & Powszechne zastosowanie \\
\hline Środek kontrolny & Kwas cytrynowy & $\begin{array}{l}\text { Uniemożliwia wytrącanie } \\
\text { się tlenków metali }\end{array}$ & $\begin{array}{l}\text { Dodatek do żywności i napo- } \\
\text { jów; sok cytrynowy zawie- } \\
\text { ra w przybliżeniu } 7 \% \text { kwasu } \\
\text { cytrynowego }\end{array}$ \\
\hline Stabilizator iłów & Chlorek potasu & $\begin{array}{l}\text { Uniemożliwia interakcję } \\
\text { płynu z iłami }\end{array}$ & $\begin{array}{l}\text { Używany w substytutach nisko- } \\
\text { sodowej soli kuchennej, lekar- } \\
\text { stwach i płynach dożylnych }\end{array}$ \\
\hline $\begin{array}{l}\text { Środek regulują- } \\
\text { cy pH }\end{array}$ & $\begin{array}{l}\text { Sód lub węglan } \\
\text { potasu }\end{array}$ & $\begin{array}{l}\text { Usprawnia działanie in- } \\
\text { nych składników, np. czyn- } \\
\text { ników umożliwiających } \\
\text { sieciowanie }\end{array}$ & $\begin{array}{l}\text { Występuje w detergentach do } \\
\text { prania, mydłach, zmiękcza- } \\
\text { czach wody i detergentach do } \\
\text { zmywarek }\end{array}$ \\
\hline $\begin{array}{l}\text { Środek uniemożli- } \\
\text { wiający zamknięcie } \\
\text { szczelin }\end{array}$ & $\begin{array}{l}\text { Krzemionka, pia- } \\
\text { sek kwarcowy }\end{array}$ & $\begin{array}{l}\text { Utrzymuje szczeliny w sta- } \\
\text { nie otwartym, co umożli- } \\
\text { wia wydostanie się gazu }\end{array}$ & $\begin{array}{l}\text { Używany w filtracji wody pit- } \\
\text { nej, piaskownicach, betonowej } \\
\text { i ceglanej zaprawie murarskiej }\end{array}$ \\
\hline $\begin{array}{l}\text { Czynnik przeciw- } \\
\text { działający osadza- } \\
\text { niu się kamienia }\end{array}$ & Glikol etylenowy & $\begin{array}{l}\text { Uniemożliwia tworzenie } \\
\text { się nalotu kamiennego } \\
\text { w rurach }\end{array}$ & $\begin{array}{l}\text { Występuje w środkach czysz- } \\
\text { czących dla gospodarstw domo- } \\
\text { wych, odmrażaczach, farbach } \\
\text { i uszczelkach }\end{array}$ \\
\hline $\begin{array}{l}\text { Substancja po- } \\
\text { wierzchniowo } \\
\text { czynna }\end{array}$ & Izopropanol & $\begin{array}{l}\text { Używany do zmniejszenia } \\
\text { ciśnienia powierzchniowe- } \\
\text { go płynów hydraulicznych } \\
\text { oraz usprawnienia odzy- } \\
\text { skiwania płynu z otworu } \\
\text { wiertniczego po wykonaniu } \\
\text { procesu szczelinowania }\end{array}$ & $\begin{array}{l}\text { Występuje w płynach do czysz- } \\
\text { czenia szkła, preparatach do } \\
\text { czyszczenia różnych rodzajów } \\
\text { powierzchni, antyperspiran- } \\
\text { tach, dezodorantach i środkach } \\
\text { do koloryzacji włosów }\end{array}$ \\
\hline Woda & Woda & $\begin{array}{l}\text { Używana w celu poszerze- } \\
\text { nia szczelin i przeniesienia } \\
\text { substancji uniemożliwiają- } \\
\text { cej ich zamknięcie (piasku) }\end{array}$ & $\begin{array}{l}\text { Kształtuje teren, używana } \\
\text { w produkcji }\end{array}$ \\
\hline
\end{tabular}

Źródło: http://www.europagazniekonwencjonalny.pl/home/technologia-wydobycia/sklad-plynu-szczelinujacego, 2 IX 2012.

Może więc rodzić się pytanie, co dzieje się z wodą, która nie jest wydobywana na powierzchnię i zostaje pomiędzy skalami po przeprowadzeniu szczelinowania. Wbrew niektórym opiniom nie przesiąka ona wcale przez glebę i nie powraca samoistnie na powierzchnię; zostaje na stałe pomiędzy skałami o bardzo niskiej przepuszczalności i nie zagraża w żaden sposób środowisku naturalnemu. Oczywiście zawsze istnieje minimalne ryzyko, że taka woda w jakiś sposób przedostanie się do wód powierzchniowych. W tym przypadku również nie ma powodów do paniki, ponieważ skład płuczki jest znany (Tabela 1) i obecne technologie pozwalają na skuteczne oczyszczanie wód z wymienionych składników chemicznych, pod warunkiem ich stałego monitorowania.

W tym miejscu należy również przyjrzeć się prawodawstwu unijnemu. Istnieje bowiem w prawie unijnym dyrektywa 2000/60/WE Parlamentu Europejskiego i Rady 
Europejskiej z dnia 23 października 2000 r. ustanawiająca ramy wspólnotowego działania w dziedzinie polityki wodnej (tzw. Ramowa Dyrektywa Wodna). Przewiduje ona zakaz bezpośrednich zrzutów zanieczyszczeń do wód podziemnych. Istnieje jednak wyjątek; od bezpośredniego stosowania tej dyrektywy można odstąpić w sytuacji, kiedy zrzut nie przeszkadza osiągnięciu celów środowiskowych przyjętych wobec danej części wód podziemnych. Postanowienia tej dyrektywy uzupełnia dyrektywa 2006/118/WP Parlamentu Europejskiego i Rady Europy z dnia 12 grudnia 2006 r. w sprawie ochrony wód podziemnych przed zanieczyszczeniem i pogarszaniem ich stanu (tzw. dyrektywa o wodach podziemnych). Obie dyrektywy wprowadzają wymóg ograniczania ewentualnych zanieczyszczeń wody do określonego poziomu. Warto jednak pamiętać, że wydobycie gazu niekonwencjonalnego nie wiąże się z zamiarem zrzucania płuczki do zasobów wodnych. W takim przypadku firmy wydobywające błękitne paliwo musiałyby dostosować skład płuczki do wymagań dyrektywy.

Oprócz wymienionych dyrektyw istnieją inne, które mogą mieć zastosowanie przy wydobywaniu gazy z lupków, ale nie zabraniają w żaden sposób prac wydobywczych, jeśli zostaną spełnione wymagane warunki ${ }^{22}$. Pod koniec października 2012 r. pojawiły się sygnały, że Komisja Europejska planuje dokładnie przyjrzeć się regulacjom dotyczącym wydobycia gazu z łupków i nie wyklucza nawet wydania odrębnej dyrektywy dotyczącej tej materii.. Wydaje się to jednak bezcelowe, ponieważ kwestie wydobywania węglowodorów są już w prawie europejskim uregulowane w wystarczający sposób.

Inne zarzuty grup prośrodowiskowych dotyczą możliwości wywołania ruchów sejsmicznych jako skutku ubocznego szczelinowania hydraulicznego. Zwolennicy wydobywania gazu z łupków odpierają ten zarzut. Prawda leży gdzieś pośrodku, ponieważ szczelinowanie hydrauliczne może rzeczywiście wpłynąć na aktywność sejsmiczną, jednak nie przekłada się ona w żaden sposób na zagrożenia dla ludzkości czy środowiska. Siła wstrząsów powstałych w wyniku szczelinowania nie jest odczuwalna na powierzchni, nawet drzewa kołyszące się na lekkim wietrze wywołują większe drgania gruntu ${ }^{23}$. Co więcej, wstrząsy powstające w ten sposób najprawdopodobniej i tak miałyby miejsce, szczelinowanie hydrauliczne jedynie przyspiesza ich następowanie. Nie ulega jednak wątpliwości, że w przypadku przeprowadzania podobnych zabiegów należy każdorazowo zachować wzmożoną ostrożnośćc ${ }^{24}$.

22 Zaliczyć do nich należy m.in.: dyrektywę 94/22/WE PE i Rady z dnia 30 maja 1994 r. w sprawie warunków udzielania i korzystania z zezwoleń na poszukiwanie, badanie i produkcję węglowodorów, rozporządzenie (WE) 1907/2006 PE i Rady z dnia 18 grudnia 2006 r. w sprawie rejestracji, oceny, udzielania zezwoleń i stosowanych ograniczeń w zakresie chemikaliów (REACH), dyrektywę 2009/147/ WE PE i Rady z dnia 30 listopada 2009 r. w sprawie ochrony dzikiego ptactwa (tzw. dyrektywa ptasia), dyrektywę Rady 92/43/EWG w sprawie ochrony siedlisk przyrodniczych oraz dzikiej fauny i flory (tzw. dyrektywa siedliskowa), dyrektywę 2006/21/WE PE i Rady z dnia 15 marca 2006 r. w sprawie gospodarowania odpadami pochodzącymi z przemysłu wydobywczego. Dyrektywa ptasia i dyrektywa siedliskowa, na której podstawie tworzone są obszary Natura 2000, mogą uniemożliwić dostęp do części terenu, na którym znajdują się zasoby gazy typu shale gas.

23 Środowiskowe aspekty..., s. 14.

24 G. Lewis, T. Smith, K.F. Perry, P. Poprawa, Wptyw poszukiwań..., s. 43. 
Osobną kwestią jest problem odpadów. Doświadczenie w wydobywaniu łupków sugeruje, że odpady powstałe w wyniku wydobycia błękitnego paliwa typu shale gas mogą zawierać materiały o nikłym poziomie radioaktywności. Co ważne, polskie łupki są łupkami górnego ordowiku i dolnego syluru i jako takie nie zawierają z natury pierwiastków radioaktywnych. Pozostałe zarzuty stawiane przez przeciwników dotyczą m.in. obniżenia wartości użytkowej terenu, ruchu ciężarowego związanego z przewozem wody i odpadów, a także poziomu hałasu i emisji podczas wydobycia ${ }^{25}$. Prowadzone są odpowiednie programy badawcze mające na celu niwelowanie tych negatywnych skutków, np. rekultywujące tereny, na których zakończono proces wydobywania gazu z lupków. W tej kwestii należy korzystać z doświadczeń Stanów Zjednoczonych i Kanady, gdzie takie tereny przeznaczano na potrzeby rolnictwa.

Przy okazji omawiania problemów środowiskowych, należy przytoczyć argumenty zawarte w dwóch dokumentach. Pierwszym z nich jest raport końcowy Państwowego Instytutu Geologicznego z badań aspektów środowiskowych procesu szczelinowania hydraulicznego wykonanego w otworze Łebień LE- $2 \mathrm{H}^{26}$. Raport zawiera następujące stwierdzenia:

1. Na granicy zakładu, przy ogrodzeniu, rejestrowano chwilowe poziomy hałasu na poziomie $77,5 \mathrm{~dB}$. Przy zabudowie mieszkalnej osiągał on poziom $53,8 \mathrm{~dB}$, nie przekraczając dopuszczalnego poziomu hałasu w środowisku dla pory dziennej ustalonego na $55 \mathrm{~dB}$.

2. Szczelinowanie hydrauliczne nie spowodowało żadnych zmian w składzie powietrza glebowego badanego pod kątem stężenia promieniotwórczego radonu i metanu.

3. Oddziaływanie na powierzchnię terenu polegało przede wszystkim na zwiększeniu obciążenia przez ustawienie urządzeń i materiałów na terenie zakładu. Było krótkotrwałe i, jak się wydaje, nie wywołało większych zmian.

4. Zabieg szczelinowania nie wywołał na powierzchni żadnych drgań lub wstrząsów mogących stwarzać zagrożenie dla budynków czy infrastruktury.

5. Proces szczelinowania hydraulicznego wytworzył niewielką ilość odpadów stałych, które zostały zagospodarowane na rekultywowanym składowisku odpadów komunalnych.

6. Płyny technologiczne znajdowały się pod stałą kontrolą - ich wyciek do środowiska nie był możliwy.

7. Nie zaobserwowano wpływu prac związanych ze szczelinowaniem na jakość wód powierzchniowych.

8. Zabieg szczelinowania, mimo wykorzystania prawie $18000 \mathrm{~m}^{3}$ wody z poziomu wodonośnego, nie wpłynął na zmniejszenie zasobów wód podziemnych w rejonie wiertni.

\section{Tamże.}

26 Badania aspektów środowiskowych procesu szczelinowania hydraulicznego wykonanego w otworze Łebień $L E-2 H$ - raport końcowy, Państwowy Instytut Geologiczny - Państwowy Instytut Badawczy, Warszawa 2011, [online] http://www.pgi.gov.pl/pl/dokumenty-in/doc_download/723-raport-z-ebienia.html, 27 VIII 2012. 
Drugim z ważnych dokumentów jest raport panelu eksperckiego ds. gazu z łupków powołanego przez amerykańską administrację na wniosek prezydenta Baracka Obamy; raport ten miał pomóc rządowi USA w zwiększeniu bezpieczeństwa szczelinowania hydraulicznego i w lepszej dokumentacji jego oddziaływania na środowisko ${ }^{27}$. Oto najważniejsze wnioski płynące z raportu, które są istotne także z polskiego punktu widzenia:

- ryzyko, że substancje szczelinujące przedostaną się do warstw płytkich, jest niewielkie;

- należy bacznie śledzić przebieg utylizacji odpadów z wierceń;

- konieczne jest wyeliminowanie z płynu szczelinującego składników oleju napędowego;

- informacja o składzie płynu szczelinującego powinna być w pełni jawna (z wyjątkiem tzw. informacji zastrzeżonej);

- należy kontynuować badania nad rozwojem technologii zmniejszającej wpływ procesu wydobywania gazu z łupków na środowisko naturalne.

Nie ma wątpliwości, że rozpoczęcie wydobycia gazu z łupków na skalę przemysłową spowoduje powstanie gigantycznej liczby miejsc pracy. Choć dokładne wykazanie skali potencjalnych zmian na polskim rynku pracy jest trudne do oszacowania ${ }^{28}$, nie ma wątpliwości, że powstaną nowe miejsca pracy w sektorach zajmujących się poszukiwaniem i wydobyciem błękitnego paliwa. Nastąpi rozbudowa przemysłu hutniczego, mechanicznego, chemicznego oraz ceramicznego. Gaz z łupków otwiera również nowe szanse dla energetyki. Przynajmniej teoretycznie możliwe jest oparcie całości zawodowej mocy wytwórczych na gazie z łupków. Byłoby to związane z potrzebą dodatkowej produkcji gazu na poziomie ok. $45 \mathrm{mld} \mathrm{m}^{3}$ rocznie $^{29}$. Jest to w praktyce oczywiście niemożliwe, jednakże samo dostosowanie się do unijnej średniej konsumpcji gazu w sektorze elektroenergetycznym spowodowałoby wzrost zapotrzebowania na błękitne paliwo o ok. $10 \mathrm{mld} \mathrm{m}^{3}$, a co za tym idzie - znaczny wzrost popytu na ten surowiec przy jednoczesnym dużym prawdopodobieństwie spadku kosztów ogólnych.

\section{WNIOSKI}

Jak wynika z dokonanej analizy, Polska stoi przed ogromną szansą. Wszelkie realne zagrożenia związane z wydobyciem gazu z łupków mogą być odpowiednio przezwyciężone. W wyniku rozpoczęcia tej gigantycznej inwestycji możemy stać się kluczowym graczem na arenie europejskiej jako poważny eksporter błękitnego paliwa. Cena gazu powinna się sukcesywnie obniżać, również dla odbiorców prywatnych, ale bę-

27 Shale Gas Production Subcommittiee 90-Day Report, Washington D.C. 2011, [online] http://www. shalegas.energy.gov/resources/081811_90_day_report_final.pdf, 2 IX 2012.

28 P. Kosowski, Obszary ryzyka..., s. 91.

29 M. Kaliski, M. Krupa, A. Sikora, Perspektywy wykorzystania gazu tupkowego w Polsce. Potencjat wzrostu konsumpcji gazu ziemnego w sektorze elektroenergetycznym, [w:] Gaz niekonwencjonalny - szansa..., s. 135. 
dzie to możliwe tylko w przypadku utworzenia wolnego i konkurencyjnego rynku. Wydobycie gazu z lupków przyniesie nowe miejsca pracy, a paliwo może zostać wykorzystane w sektorze energoelektrycznym do masowej produkcji energii elektrycznej. Końcowym efektem będzie znaczny rozwój gospodarczy oraz wzrost PKB. Nie do przeceniania jest również fakt, iż pozyskiwanie gazu ziemnego z własnych złóż przełoży się bezpośrednio na wzrost bezpieczeństwa narodowego RP. Jednakże warunkiem absolutnie koniecznym i pierwszym, który musi się spełnić, jest potwierdzenie optymistycznych prognoz na temat złóż gazu z łupków w Polsce. Szacunkowe prognozy są bardzo różne, dlatego spełnienie się wszelkich prognoz opisanych w niniejszym artykule będzie mogło mieć miejsce jedynie w przypadku, gdy prawdziwe okażą się te najbardziej optymistyczne.

\section{BIBLIOGRAFIA}

\section{Publikacje książkowe:}

\section{Literatura pomocnicza:}

- Prace zbiorowe:

Bezpieczeństwo energetyczne Polski 2010 - raport otwarcia, red. P. Szlagowski, Kraków 2010.

- Rozdziały w pracach zbiorowych:

Kaliski M., Krupa M., Sikora A., Perspektywy wykorzystania gazu niekonwencjonalnego w Polsce. Potencjat wzrostu konsumpcji gazu ziemnego w sektorach pozaenergetycznych oraz gtówne bariery dla rozwoju sektora gazu niekonwencjonalnego, [w:] Gaz niekonwencjonalny - szansa dla Polski i Europy? Analiza i rekomendacje, red. I. Albrycht, Kraków 2011.

Kołaczkowski M., Liberalizacja rynku gazu i wzrost bezpieczeństwa energetycznego [w:] Gaz niekonwencjonalny - szansa dla Polski i Europy? Analiza i rekomendacje, red. I. Albrycht, Kraków 2011.

Kosowski P., Obszary ryzyka mogace warunkować znaczenie sektora gazu tupkowego w Polsce i jego wptyw na wartości realne w gospodarce, [w:] Wptyw wydobycia gazu tupkowego na rozwój spoteczno-ekonomiczny regionów - amerykańskie „success story” i potencjalne szanse dla Polski, red. I. Albrycht, Kraków 2012.

Lewis G., Smith T., Perry K.F., Poprawa P., Wptyw poszukiwań i wydobycia gazu niekonwencjonalnego na środowisko naturalne, [w:] Gaz niekonwencjonalny - szansa dla Polski i Europy? Analiza i rekomendacje, red. I. Albrycht, Kraków 2011.

Kaliski M., Krupa M., Sikora A., Perspektywy wykorzystania gazu tupkowego w Polsce. Potencjat wzrostu konsumpcji gazu ziemnego w sektorze elektroenergetycznym, [w:] Gaz niekonwencjonalny - szansa dla Polski i Europy? Analiza i rekomendacje, red. I. Albrycht, Kraków 2011.

Poprawa P., Zasoby i potencjat gazu niekonwencjonalnego, [w:] Gaz niekonwencjonalny - szansa dla Polski i Europy? Analiza i rekomendacje, red. I. Albrycht, Kraków 2011.

Ruszel M., Perspektywy eksportu gazu niekonwencjonalnego z Polski do krajów Europejskich, [w:] Gaz niekonwencjonalny - szansa dla Polski i Europy? Analiza i rekomendacje, red. I. Albrycht, Kraków 2011. 
Rychlicki S., Siemek J., Gaz niekonwencjonalny - charakterystyka ztóż i technologia wydobycia, [w:] Gaz niekonwencjonalny - szansa dla Polski i Europy? Analiza i rekomendacje, red. I. Albrycht, Kraków 2011.

Zawisza A., Perspektywy rozwoju gazu niekonwencjonalnego w Polsce - system koncesyjno-podatkowy, [w:] Gaz niekonwencjonalny - szansa dla Polski i Europy? Analiza i rekomendacje, red. I. Albrycht, Kraków 2011.

\section{Publikacje elektroniczne:}

\section{Literatura źródłowa:}

Mapa koncesji na poszukiwanie i rozpoznawanie gazu tupkowego - stan na dzień 31.07.2012 r., [online] http://www.mos.gov.pl/g2/big/2012_08/ceba3f13cd61cf46d16a3c41ffbfb80a.jpg.

\section{Literatura pomocnicza:}

\section{- Prace zbiorowe:}

Badania aspektów środowiskowych procesu szczelinowania hydraulicznego wykonanego w otworze Eebień LE-2H - raport końcowy, Państwowy Instytut Geologiczny - Państwowy Instytut Badawczy, Warszawa 2011, [online] http://www.pgi.gov.pl/pl/dokumenty-in/doc_download/723-raport-z-ebienia.html.

http://www.europagazniekonwencjonalny.pl/home/technologia-wydobycia/sklad-plynu-szczelinujacego.

Ocena zasobów wydobywalnych gazu ziemnego i ropy naftowej w formacjach tupkowych dolnego paleozoiku w Polsce (basen battycko-podlasko-lubelski). Raport pierwszy, Państwowy Instytut Geologiczny - Państwowy Instytut Badawczy, 2012, [online] http://www.pgi.gov.pl/pl/ component/docman/doc_download/771-raport-pl.html.

Shale gas outlook: A U.S. perspective, KPMG Global Energy Institute, [online] http://www. kpmg.com/Global/en/IssuesAndInsights/ArticlesPublications/shale-gas/Documents/ shale-gas-us-outlook.pdf.

Shale Gas Production Subcommittiee 90-Day Report, Washington D.C. 2011, [online] http:// www.shalegas.energy.gov/resources/081811_90_day_report_final.pdf.

Środowiskowe aspekty poszukiwań i produkcji gazu ziemnego tupkowego i ropy naftowej tupkowej, Ministerstwo Środowiska oraz Państwowy Instytut Geologiczny - Państwowy Instytut Badawczy, 2011, [online] http://www.mos.gov.pl/g2/big/2011_08/d048c148f02734c384a119266ba159b8.pdf.

World Shale Gas Resources: An Initial Assessment of 14 Regions Outside the United States, U.S. Energy Information Administration, 2011, [online] http://www.eia.gov/analysis/studies/ worldshalegas/pdf/fullreport.pdf.

Zestawienie koncesji na poszukiwanie i rozpoznawanie ztóż gazu tupkowego w Polsce wraz zich lokalizacja wedtug stanu na dzień 1 sierpnia 2012 r., [online] http://www.mos.gov.pl/g2/ big/2012_08/89223b29e1148090ca950f6c50913f7c.pdf.

\section{- Artykuły w czasopisamach naukowych:}

Hardo J., Strategia poszukiwań ztóż gazu ziemnego w tupkach, „Przegląd Geologiczny” 2010, Vol. 58, nr 3, [online] http://www.pgi.gov.pl/images/stories/artykuly/gaz_lupkowy/pg_2010_03_15.pdf. 
Kijewski T., Perspektywy rozwoju wydobycia niekonwencjonalnych ztóż gazu ziemnego w kontekście zwiększenia bezpieczeństwa energetycznego RP, „Bezpieczeństwo Narodowe” 2010, $\mathrm{nr} 13$, [online] http://www.bbn.gov.pl/download.php?s=1\&id=4596.

\section{- Artykuły prasowe:}

Furman T., Biznes obawia się nowych podatków, „Rzeczpospolita”, 16 X 2012, [online] http:// www.rp.pl/artykul/938633,942781-Biznes-obawia-sie-nowych-podatkow.html.

Szczelinowanie hydrauliczne: Polacy od 60 lat stosuja kontrowersyjna technologię, [online] http:// forsal.pl/artykuly/611640,szczelinowanie_hydrauliczne_polacy_od_60_lat_stosuja_kontrowersyjna_technologie.html.

Tomasz KLEPNER, absolwent studiów double degree I stopnia na kierunkach politologia na Uniwersytecie Jagiellońskim i scienze politiche e internazionali na LUMSA Università di Roma, student prawa, stosunków międzynarodowych i bezpieczeństwa narodowego na Uniwersytecie Jagiellońskim. Aktualnie współpracownik, a wcześniej stażysta w Instytucie Kościuszki. Były praktykant w Biurze Obsługi Prawnej i Funkcjonariuszy Służb Mundurowych Ministerstwa Spraw Wewnętrznych i Administracji oraz w Biurze Administracyjnym Ministerstwa Rozwoju Regionalnego.

Opinie wyrażone w niniejszej publikacji sa jedynie prywatnym pogladem Autora i nie odzwierciedlaja oficjalnego stanowiska programowego Instytutu Kościuszki. 